\title{
Curriculum
}

\section{Bridging the Gap between Secondary and Higher STEM Education - The Case of STEM@school}

JOLIEN DE MEESTER ${ }^{1}$, JELLE BOEVE-DE PAUW ${ }^{2}$, MARIE-PAULE BUYSE ${ }^{3}$, STIJN CEUPPENS ${ }^{3}$,

MIEKE DE COCK ${ }^{4}$, HAYDÉE DE LOOF ${ }^{2}$, LEEN GOOVAERT S ${ }^{5}$, LUC HELLINCK X ${ }^{6}$, HEIDI KNIPPRATH ${ }^{7}$, ANNEMIE STRUYF ${ }^{8}$, LIEVE THIBAUT ${ }^{9}$, DIDIER VAN DE VELDE ${ }^{10}$, PETER VAN PETEGEM ${ }^{2} \&$ WIM DEHAENE 3

${ }^{1}$ Faculty of Engineering Science, KU Leuven, BE 3000 Leuven, Belgium. Email: Jolien.DeMeester@kuleuven.be

${ }^{2}$ Department of Training and Education Sciences, University of Antwerp, BE 2000 Antwerp, Belgium

${ }^{3}$ Department of Electrical Engineering ESAT-MICAS, KU Leuven, BE 3000 Leuven, Belgium

${ }^{4}$ Department of Physics and Astronomy, KU Leuven, BE 3000 Leuven, Belgium ${ }^{5}$ Faculty of Social Sciences/School of Education, University of Antwerp, BE 2000 Antwerp, Belgium

${ }^{6}$ Logistic Unit, Vrije Universiteit Brussel, BE 1000 Brussels, Belgium

${ }^{7}$ Research Institute for Work and Society, KU Leuven, BE 3000 Leuven, Belgium ${ }^{8}$ Department of Sociology, University of Antwerp, BE 2000 Antwerp, Belgium 9 i-Learn, IMEC, BE 3000 Leuven, Belgium

${ }^{10}$ Pedagogical Support, Katholiek Onderwijs Vlaanderen, BE 1000 Brussels, Belgium

Our rapidly changing society needs highly-qualified STEM professionals (experts in science, technology, engineering, and mathematics) to develop solutions to the problems it is facing. Many of the students who graduate from a STEM programme in secondary education, however, opt out of STEM when enrolling in higher education, often due to a loss of interest. To ensure sufficiently high and qualified enrolment in higher STEM education, we need to bridge this gap between secondary and higher STEM education by showing our youngsters the relevance of science and technology to their personal life and environment. To this end, the project STEM@school 
promoted and studied the idea of integrated STEM in secondary education in Flanders, Belgium. In integrated STEM education, learning contents from the separate STEM courses are linked in an authentic way, as they often are in our environmental challenges. This approach encourages students as well as their teachers to acquire a robust understanding of STEM concepts, and a creative, inquisitive, and collaborative mindset. For the design of integrated STEM curricula, STEM@school united secondary-school STEM teachers and university researchers. This article elaborates on the principles, opportunities and challenges of the design and implementation of these curricula and discusses their promising effects on students' conceptual understanding and attitudes towards STEM subjects. The article concludes with tips and tricks to get started with integrated STEM education in secondary schools.

To remain at the cutting edge in our global, information-based and technologydriven economy, Europe needs people competent in science, technology, engineering and mathematics (STEM). The STEM sectors, and with them the labour market and job vacancies in STEM (particularly in mathematics, computer science and engineering) are growing much faster than those of non-STEM sectors (World Economic Forum 2016; European Commission 2010; Caprile et al. 2015). Twenty-first century competencies and transferable skills, inherent to cognitively demanding STEM practices, become indispensable qualities of future employees (World Economic Forum 2016; EU STEM Coalition 2016). Higher STEM education plays a substantial part in providing such a competent workforce. However, in order to deliver sufficient and sufficiently qualified STEM graduates, higher-education institutions must attract a significant number of competent and motivated students into STEM programmes. This is where the gap, focused upon in this paper, occurs. STEM-oriented programmes experience a considerable drop-out at the transition from secondary to higher education and in the first years of higher education (Aschbacher et al. 2010; Chen 2013). Therefore, we must return to an earlier stage of the educational system and focus on secondary STEM education, from the perspective of higher STEM education. Today's secondary education in STEM is facing two major challenges that must be tackled in order to diminish the gap between secondary and higher STEM education. This section elaborates on these two challenges and sets the scene for presenting STEM@school, a project that examined the impact of a new approach to STEM education in secondary schools in Flanders, Belgium. ${ }^{1}$

The first challenge is that, despite the relatively high interest in STEM programmes in secondary education, many students who graduate from these programmes opt out of STEM when enrolling in higher education. Tertiary STEM programmes are already less popular than non-STEM programmes. In Europe, fewer than one out of three students in higher education is enrolled in a STEM programme (Eurostat 2018). With only about $20 \%$ of its students signing

1. STEM@school was funded by the Agency for Innovation through Science and Technology (IWT) of the Flemish government. 
up for higher STEM education, the Flemish part of Belgium not only lags behind the European average, it also loses more than half of its students who were enrolled in a STEM programme in secondary education to non-STEM programmes in higher education (Flemish Government 2015, 2018; Van den Berghe and De Martelaere 2012). Students enrol in a higher-education programme because they have career aspirations in that area (Morgan et al. 2013). Youngsters' inclination to pursue a career in STEM is dependent on their academic performance, their self-efficacy, and their interest in science and technology and of their perception of the usefulness of science and technology for their future life and for society (OECD 2016; Kolmos et al. 2013; Sheldrake et al. 2017). These motives are, however, not mutually independent (OECD 2016). The Relevance of Science Education (ROSE) study revealed that although the majority of European youngsters believe they can personally influence what happens in their environment, they do not believe science and technology are means to do so (Sjøberg and Schreiner 2010). Additionally (or possibly as a result), they show a deplorably low interest in STEM (Sjøberg and Schreiner 2010). Students' image of careers in science and technology (or lack thereof) also has an influence on interest retention (Cleaves 2005). Many students regard STEM jobs as very difficult and risky (i.e. prone to financial instability), with few practical or creative opportunities (Bennecke and Lohel 2009). Students who lack a robust self-efficacy in science are easily repelled by this inadequate image and are consequently driven away from pursuing STEM pathways (Aschbacher et al. 2010; Becker 2010; Cleaves 2005). The first challenge is thus to counteract these reasons underpinning the dropout from secondary to higher STEM education.

The second challenge faced by secondary STEM education is the ever-trending question of how to equip students with the literacy, higher-order skills and twenty-first century competencies required in higher STEM education and in European society in general (Conley 2007). Creative solutions to environmental problems require a thorough understanding of basic STEM concepts and ideas, but also the ability to make cross-disciplinary connections (NAE and NRC 2014; Streveler et al. 2008). In this respect, not the amount of knowledge is important, but rather the depth of understanding and the ability to generate and apply insights to solve problems. This ability is measured by the OECD's Programme for International Student Assessment (PISA). Most European students scored above the OECD's mean in PISA 2015, as did Belgian students (OECD 2016). However, when comparing the results in science and mathematics of 2015 with those of 2006 and 2012, few European countries managed to raise or even maintain the average performance of their students (OECD 2016). Neither did Belgium (OECD 2016). Along with the ability to apply scientific and technological insights to solve problems, other twenty-first century competencies become increasingly important. Industry representatives stress the need for a range of critical thinking skills, such as inquisitiveness, logical and analytical thinking, self-regulation, decision making, and creativity (World Economic Forum 2016; Dumitru et al. 2018; Rayner and Papakonstantinou 2015). Critical thinking facilitates the detection of flaws in a reasoning process, and the assessment of the quality of a decision or a solution to 
a problem (Halpern 1998). The second challenge thus consists of gradually providing secondary STEM students with the skills set expected of prospective first-year STEM undergraduates.

In sum, students lack a sense of the relevance of science and technology to environmental issues, have a faulty image of, and lack training in, the everyday practices and competences of STEM professionals, which results in low levels of interest and decreasing performance among students in STEM. The lack or loss of interest in science and technology among European youngsters strongly contrasts with our world's growing problems, which call for urgent technological innovation based on scientific research (e.g. issues of energy, sustainability, aging, and climate change). But how does compulsory secondary education play a role in this mismatch? The ROSE study reveals that science as it is taught at school does not help students realize its importance to society (Sjøberg and Schreiner 2010). The often fragmented manner in which STEM courses, such as mathematics, physics, geography, mechanics, and electricity, are taught in secondary education does not appeal to students, and causes them to lose their interest in science and technology (English 2017). Furthermore, school science does not resemble real-world science (Fortus et al. 2005; Williams 2011), and therefore does not prepare students to tackle real-world problems, which often require the interdisciplinary application of competencies from different STEM disciplines (Capraro and Jones 2013; English 2017). Conversely, classroom practices that reflect authentic applications of science and technology can positively impact students' affinity with STEM (OECD 2016; Aschbacher et al. 2010; Sheldrake et al. 2017). A new approach to secondary STEM education thus proves to be necessary, in which STEM subject matter is made relevant for students by exposing the connections between the different STEM courses.

Integrated STEM or iSTEM education can show students the relevance of science and technology to their everyday life and environment. Integrated STEM education emphasizes the interdisciplinary links between STEM concepts and skills while ensuring deep insight into each of the separate STEM disciplines by creating the need to learn and link these concepts and skills in the context of authentic problems (Kelley and Knowles 2016; Shernoff et al. 2017; English 2017).

Research has shown that students who participated in an integrated STEM curriculum demonstrate an improved performance on standards-based science, mathematics, and integrated science/mathematics problems (Becker and Park 2011; Kiray and Kaptan 2012). Integration of STEM contents also positively affects students' problem-solving, analysis and modelling skills (Ross and Hogaboam-Gray 1998; Satchwell and Loepp 2002). Furthermore, it enhances students' sense of relevance and importance of STEM subjects to environmental issues and future careers (Kutch 2011; Tseng et al. 2013). Students schooled in iSTEM exhibit a higher self-efficacy in science, motivation for learning, and interest in engineering careers (Kutch 2011; Tseng et al. 2013; Ross and Hogaboam-Gray 1998). Integrated STEM education empowers teachers to inspire their students, inform them about STEM professions, and create a safe learning environment in which they can ask questions and in which efforts in problem solving are praised (Aschbacher et al. 
2010; Cleaves 2005). As such, iSTEM education encourages students to pursue STEM pathways and to take up a responsible role in our ever-developing scientifically- and technologically-driven society.

\section{The Research Project STEM@school}

\section{Premise and Planning}

Based on the rationale that iSTEM can make STEM subject matter more relevant to students and consequently enhance both their understanding and interest in STEM, the research project STEM@school (http://www.stematschool.be/en/) was established in a collaboration between two Flemish universities and two Flemish secondary-education umbrella organizations (Knipprath et al. 2018). The aims of STEM@school were to develop an approach and a curriculum for iSTEM education in Flanders (Belgium) and to assess the effects of this approach on students' performance and attitudes towards STEM. As such, STEM@school set out to meet several of the objectives of the 'STEM Action Plan' of the Flemish government. This plan called out for initiatives that provide attractive STEM curricula, go for excellence, empower teachers, enhance the process of choosing a career, and/or increase the appreciation of technical professions in order to increase the number of graduates in scientific and technical study domains (Flemish Government 2012). The design-based research set up by STEM@school was funded by the Agency for Innovation through Science and Technology, which was later incorporated by the Fund for Scientific Research (FWO - Fonds Wetenschappelijk Onderzoek) in Flanders. STEM@school started in June 2014 and ended in June 2018.

Although education for STEM literacy is beneficial for every student (Meeder 2014), STEM@school was specifically oriented towards students who have a predisposition to abstract scientific thinking (De Meester et al. 2015). This decision was made to narrow the scope of the curriculum development. Two study options of Flemish secondary education focus on this type of students: the 'Sciences' option in the general track, and the 'Industrial Sciences' option in the technically-oriented track. These study options provide a high number of mathematics and (applied) science classes and prepare students for a continuation of their studies towards a bachelor's or master's degree in higher STEM education. Hence, STEM@school aimed to bridge the gap between secondary and higher STEM education by bridging the gap between the separate STEM courses.

The four project years were more or less synchronized with school years and encompassed four cycles of design, implementation and assessment of iSTEM learning units in grades 9 to 12 , that is to say the final three years of secondary-school education in Belgium. During each cycle, two or three iSTEM learning units were designed for grade $i$ while the learning units of grade $i-1$ were being implemented and reviewed. Students' knowledge and transfer ability with regard to STEM subjects, their attitudes towards STEM, and teachers' attitudes and practices towards STEM were assessed through pre- and post-tests, classroom observations, 


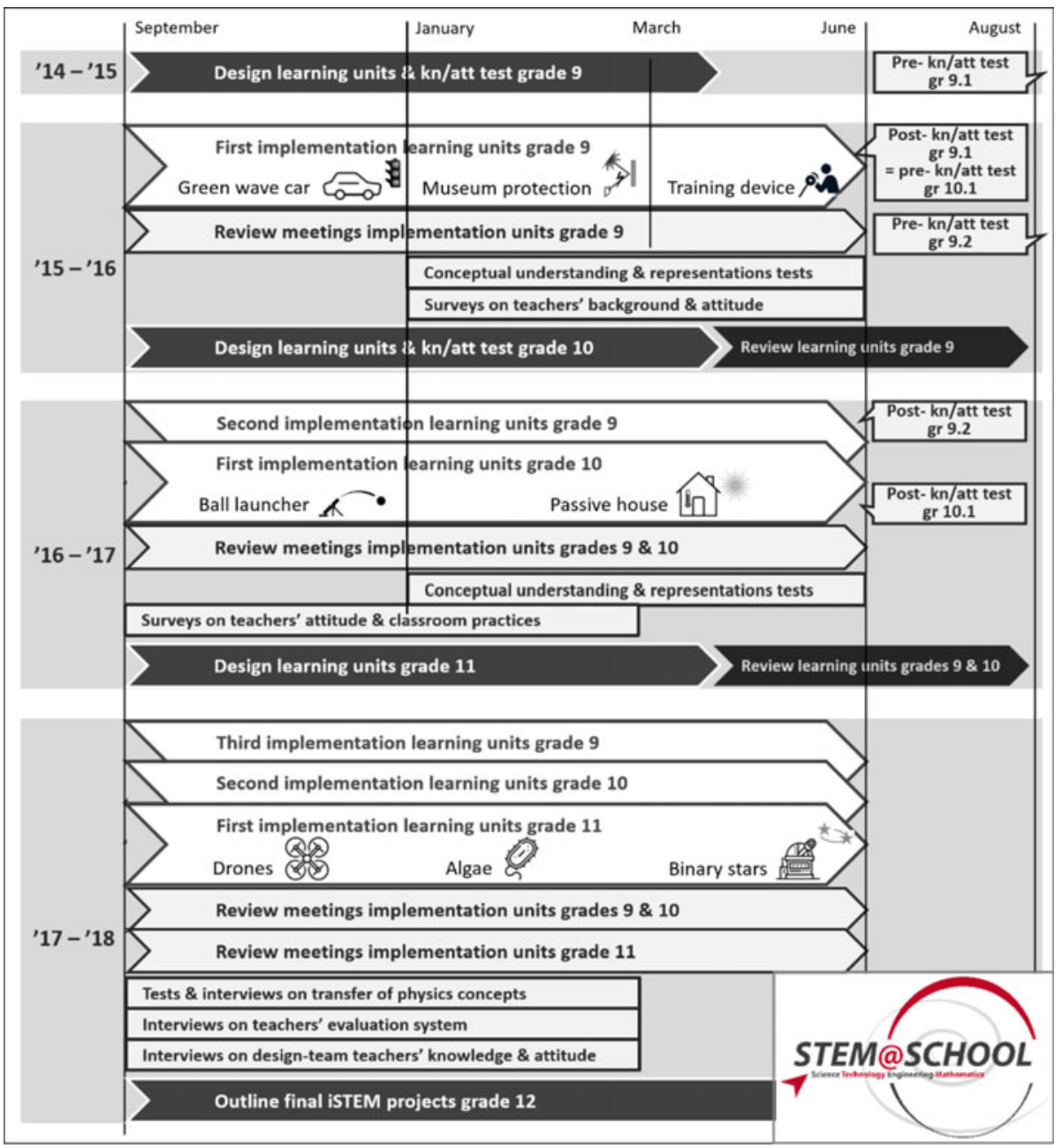

Figure 1. Planning of the research project STEM@school.

interviews, and surveys. The planning of these design, implementation, and assessment phases is shown in Figure 1. The methodology and results of this design and implementation are elaborated in the following sections.

\section{Design and Research Methodology}

STEM@school adopted a design-based, quasi-experimental methodology for the development and assessment of the iSTEM learning units. At the time, a curriculum for integrated STEM, tailored to the Flemish educational system, was non-existent and had to be developed from scratch before its effects could be measured. Through the development process, a suitable approach to iSTEM was bottom-up constructed, and later-on used as a reference framework against which the effects were evaluated. 
To bridge the gap between secondary and higher STEM education beyond the alignment of STEM competencies, STEM@school established an alliance between secondary-school STEM teachers and university researchers, not only for the implementation, but also for the development of the iSTEM curriculum. This alliance, in the form of integrated STEM teacher design teams (iSTEM TDTs), allowed an exchange of insights from within the classroom and insights from international, educational research. STEM@school composed its ten iSTEM TDTs in such a way that, within each TDT, each of the STEM disciplines was represented by at least one teacher with expertise in this domain. Moreover, the iSTEM TDTs consisted of teachers from different schools and from different grades. They were coached by a scientifically or technically schooled researcher from one of the universities. In the first meeting of a design cycle, all TDTs gathered to decide upon the different themes around which the learning units should be developed. From then on, the members of each TDT met on a regular basis (at least once a month) to develop a learning unit for the theme that was assigned to them. The process of the iSTEM TDTs when developing learning units was examined via case study research, in which the design steps, made by the TDTs, and their finally designed learning units were analysed qualitatively (De Meester 2019).

In the year following the design of the learning units for a particular grade, teacher teams from 26 schools implemented the units in their classrooms. During the implementation, teachers, pedagogical counsellors and researchers gathered regularly to share their experiences, the problems and successes they encountered, and their lessons learned. During these sessions, teachers gave input to improve the learning units. This feedback was implemented at the end of the school year so the revised learning units could be tested in the following year, while the newly designed units were being implemented for the first time in the higher grade.

A quasi-experimental research approach with both quantitative and qualitative analysis methods was adopted to assess the implementation and the impact of the iSTEM learning units. To examine the implementation of the key principles of iSTEM education, a survey method was used to measure teachers' instructional practices (Thibaut et al. 2018b). Moreover, to get a more nuanced and detailed insight into these instructional practices, classroom observations were held and teacher interviews were conducted to specifically examine teachers' use of effective assessment strategies (Goovaerts 2019) and their attitudes towards teaching (i)STEM as a result of participating in the iSTEM TDTs (De Meester 2019). Additionally, surveys were taken to determine the impact of teachers' school context and personal factors on their attitudes towards teaching iSTEM (Thibaut et al. 2018c).

Learning outcomes in terms of students' attitudes and understanding of STEM concepts as a result of participating in the iSTEM education were examined in depth, but also through a longitudinal large-scale study, while controlling for prior attitudes and knowledge. To this end, various instruments were developed and administered. A pre-test for students' knowledge and attitudes was conducted at the start of the project and post-tests were conducted yearly. These tests measured students' STEM literacy (i.e. mathematics, physics, technology, research and design skills, 


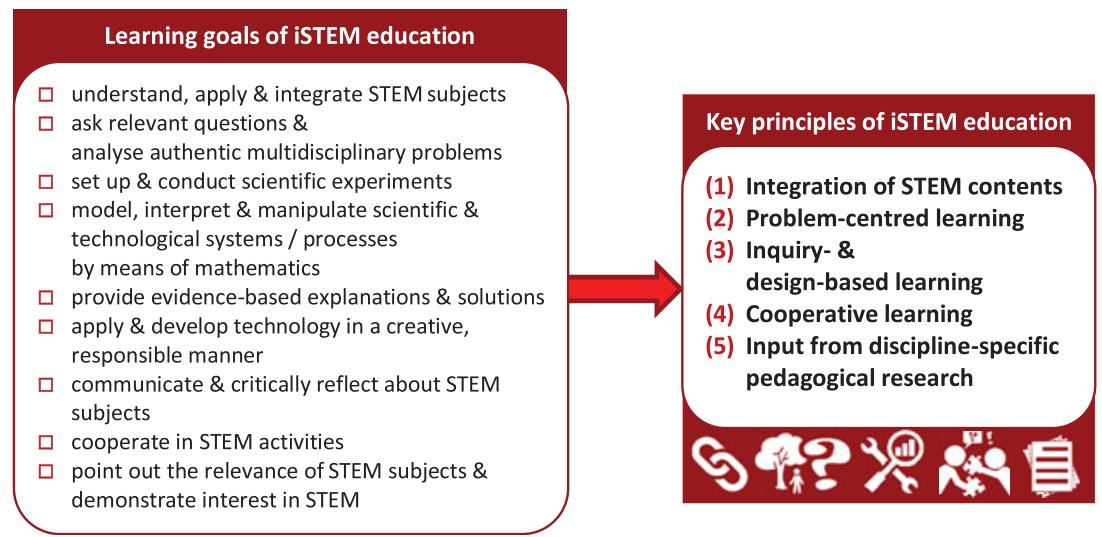

Figure 2. Learning goals and key principles of iSTEM education.

and the ability to apply STEM knowledge in an integrated way) and attitudes towards STEM (De Loof 2019). In total, 38 schools were invited to complete the tests: 26 test schools that implemented the iSTEM learning units (i.e. the experimental group) and 12 control schools that did not adopt the learning units (i.e. the comparison group). Students of sub-sets of these groups were given additional tests to examine more deeply specific aspects of students' knowledge, such as their ability to transfer knowledge from one STEM domain to the other (Ceuppens et al. 2019; Goovaerts 2019). Finally, classroom practices were videotaped and observed to assess students' collective engagement during iSTEM lessons (Struyf et al. 2019).

\section{Major Results and Findings}

iSTEM Learning Units Should be Standards-based and Should Address Five Key Principles

Once the targeted iSTEM learning goals were clearly defined (see Figure 2), eight iSTEM learning units were developed by means of a design-based approach (Barab and Squire 2004), as shown in Figure 1. In the development of the learning units, the TDTs were encouraged to illuminate the interdisciplinary cohesion of STEM subject matter, while warranting the specific identity and knowledge base of each of the separate STEM disciplines (NAE and NRC 2014; English 2017). It quickly became clear that the learning materials had to be grounded in the curricula of the different STEM courses, as the first discussions of the TDTs almost exclusively revolved around the curriculum standards of the particular target group. In Flemish secondary education, the breadth of standards to be met and the density of the class timetables leave little room for addressing topics other than those mentioned in the STEM course curricula. Therefore,STEM@school decided not to create just small projects, but to develop learning units that covered a whole trimester and that addressed a significant number of curriculum standards of each STEM course. As such, the STEM@school units differ from the output of many other iSTEM 
initiatives in that they do not merely aim for science popularization. Rather, they want to establish a robust understanding and connection of the different STEM subjects and create a more lasting impact on students' motivation for learning STEM subject matter. One hour of mathematics and (applied) physics, one hour of chemistry, biology or geography (depending on the course contents addressed in the learning unit), and two to three spare hours for design and inquiry were allocated weekly to the implementation of the iSTEM learning unit.

Through the iterative design of the learning units, an approach towards iSTEM arose bottom-up (Reeves et al. 2005). Via a systematic review of the literature on learning theories and instructional practices in iSTEM (Thibaut et al. 2018a), this approach was scientifically validated and fine-tuned. The approach to iSTEM was constituted by five key principles: (1) integration of STEM learning contents; (2) problem-centred learning; (3) inquiry- and design-based learning; (4) cooperative learning; and (5) input from discipline-specific pedagogical research. Furthermore, the design of the learning units was inspired by Perkins' (2010) idea of making learning whole. Perkins compares students' learning with playing a game and encourages curriculum developers to provide a junior version of the real game. In the case of STEM@school, this idea was translated into developing learning activities that reflect real-world STEM practices (De Meester et al. 2015). The learning units of STEM@school each consisted of an authentic, central challenge, triggering the need to learn and connect STEM concepts and skills via evidence-based learning activities. These activities encourage students to work in teams and to set up and realize experiments or prototypes in order to provide a solution to the challenge at hand, just as professional scientists and engineers would do. Together with the learning goals and the instructional practices, the assessment of STEM practices also needed a makeover, in order to ensure constructive alignment (Biggs 1996).

During the design of the iSTEM learning units, a new assessment strategy with a focus on process evaluation was designed based on a literature review and feedback from assessment experts (Goovaerts et al. 2016).

In the very first learning unit, students of Grade 9 are challenged to design and build a scale model of a car that can autonomously drive through a predefined green wave of traffic lights (De Meester 2019). The students must programme their model car in such a way that it reaches the finish line as quickly as possible, without having to stop for any of the three given traffic lights on the road, and without exceeding a given speed limit (Figure 3). In this learning unit, students acquire technical and engineering competencies such as rescaling, modelling, choosing suitable mechanisms, and programming. Meanwhile, students discover that they need knowledge about the concepts 'time', 'position', 'velocity' and 'acceleration', and about the mathematical relationships between these concepts and how to translate them into algorithms to control the car. Specific exercises were included to counteract some of the student misconceptions frequently addressed in the research literature on these physics concepts (Ceuppens 2019).

A learning unit for the second semester of Grade 10 calls upon students to build a model of a passive house with a sun boiler, in which the hot water of the sun boiler 


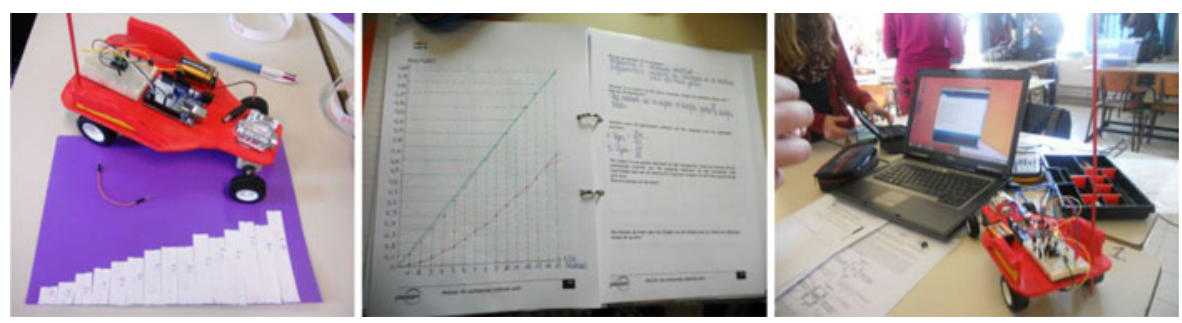

Figure 3. Experimentation, modelling and programming in the Green Wave Car unit.

flows through the floor heating system. The temperature of the house must be controlled by an on/off control system. Students thus have to use equations of heat transfer and mathematical modelling to simulate the behaviour of the feedback system and to adapt the dimensions and materials of the model house to optimize this behaviour (Goovaerts et al. 2019a, 2019b). Other learning units challenge students to develop a security system by means of reflecting laser beams, to design a rehabilitation device for a student who got impaired by a car accident, to develop an ecofriendly application of algae cultivation, or to build a computer program to analyse real astronomical data and to describe the motion of a binary star. By addressing environmental or social issues and by including engineering design as well as scientific inquiry and modelling, the whole of these challenges aims to pique and retain the interest of a varied set of student profiles. These profiles range from those who might be drawn by the ability of STEM to help people (Aschbacher et al. 2010) to those who might identify with the clearer image of real STEM practices brought by these challenges (European Commission 2010).

\section{iSTEM can Contribute to Students' Engagement as well as to their Understanding in STEM Subjects}

Classroom activities during iSTEM lessons were compared with activities during lessons of discipline-specific STEM courses (physics, mathematics) in terms of student engagement (Reeve et al. 2004) and student-centredness (Sawada et al. 2002). The quantitative and qualitative analyses of the classroom observations and focus group interviews showed that students' collective classroom engagement was higher during iSTEM lessons than during the regular, segregated STEM lessons, owing to the high level of student-centredness of the iSTEM lessons (Struyf et al. 2019). The qualitative analysis furthermore revealed that, besides student-centredness, the integration of STEM learning contents and the problem-centred approach of the iSTEM lessons can be engaging for students (Struyf et al. 2019).

To measure the impact of the iSTEM approach on students' interest, attitudinal questionnaires (Ardies et al. 2013) were administered to students of the experimental group and to those of the control group prior to and after each year of implementation of the iSTEM learning units. The quantitative analysis revealed that students in the experimental group (exposed to the iSTEM approach) reported more positive 
attitudes towards STEM than the students in the control group (De Loof 2019). Even after controlling for social economic status, gender, study track and abstract reasoning ability, the type of STEM education (integrated or traditional) explained a significant part of the variance. Students in the iSTEM condition reported being more interested in mathematics, science, and technology and showed more interest in pursuing a scientific career compared with the students in the control group (De Loof 2019). In fact, whereas the attitudes towards STEM of students of the control group were deteriorating over time, those of the experimental group remained rather stable (De Loof 2019). However, the iSTEM approach had a slightly negative effect on students' self-efficacy in mathematics and science, possibly because they perceived mathematics and science subject matter as more difficult when it was being applied in an integrated way (De Loof 2019). This issue will be addressed in future developments and will probably also be mitigated when integrated education in general becomes the norm.

To assess the effect of iSTEM education on students' cognitive learning outcomes, tests were administered to students of both the experimental and the control group prior to and after each year of implementation. Results showed that, after two years, students involved in iSTEM education scored significantly better than their counterparts in traditional STEM education in terms of mathematical knowledge and application and in terms of technological knowledge (De Loof 2019). However, no significant difference was found in terms of knowledge and application of physics concepts, in terms of integration of mathematics and physics, or in terms of inquiry skills (De Loof 2019). Nonetheless, when taking teachers' actual instructional practices into account (i.e. the level of implementation of the key principles of iSTEM education), rather than simply comparing the scores of the experimental group with those of the control group, a significant effect of iSTEM education on students' knowledge of physics and integrated concepts in the 10th grade was found as well (Thibaut 2018).

An in-depth study focused on one of the main physics concepts in the first iSTEM learning unit for the 9th grade (the Green Wave Car unit). An adapted version of a multiple-choice test on kinematics concepts (Lichtenberger et al. 2017) was administered to 199 students enrolled in iSTEM education and to 197 students enrolled in traditional STEM education to examine the presence of misconceptions (Ceuppens 2019). The comparison shows a significant advantage of the iSTEM students over those in the traditional STEM education, which can be attributed to the integrated learning approach (Ceuppens 2019). This advantage might be partly due to the longer amount of time spent on the application of 1D kinematics concepts in the real-world challenge of the learning unit. However, the effect size was small and students' general performance on this test was still unsatisfactory (Ceuppens 2019). This led the research team of STEM@school to create additional learning materials to complement the Green Wave Car unit, in which extra attention is paid to the difficulties that emerged from the test results.

Other cognitive test instruments were developed and administered in the context of STEM@school. One test assessed students' fluency to translate between representations (graph, formula and table) (Ceuppens et al. 2018). Another test examined 
students' conceptual understanding and strategies when dealing with linear functions in isomorphic mathematics and kinematics problems (Ceuppens et al. 2019). Furthermore, students were interviewed while they were solving isomorphic kinematics and thermodynamics problems in order to study their strategies when dealing with the interdisciplinary concepts of slope, area under a curve, and resistance (Goovaerts 2019). Each of these studies compared the performance of students enrolled in iSTEM education with the performance of students enrolled in traditional STEM education. Apart from the fact that iSTEM students more often correctly calculated the slope of a curve (Ceuppens et al. 2019), no other significant differences between the students of both groups could be distinguished (Ceuppens et al. 2018; Goovaerts 2019). Even though STEM@school hoped to considerably enhance students' ability to transfer concepts across contexts by its integrated approach, these results are reassuring in that STEM@school managed to retain students' conceptual understanding in STEM while significantly changing the educational approach.

\section{Creating Positive Teacher Attitudes towards iSTEM is Crucial to the Implementation of iSTEM}

STEM@school investigated how the implementation of iSTEM education in the classroom is related to students' learning outcomes on the one hand, and to teachers' attitudes and background and personal factors on the other hand. One study linked the results of one of the aforementioned tests on students' cognitive learning outcomes to the results of a survey that questioned students on the extent to which each of the five key principles of iSTEM education was being applied in their (i)STEM classes (Thibaut 2018). Multilevel regression analyses revealed that instructional practices in iSTEM are predictive of students' performance on mathematical and integrated mathematics-physics problems. Classroom activities involving problem-centred and cooperative learning particularly favour students' performance in mathematics, whereas integration of STEM contents positively affects their performance in physics (Thibaut 2018).

Through analysis of teacher surveys, another study found that teachers' selfreported enactment of the key principles of iSTEM education significantly depends on teachers' attitudes towards iSTEM (i.e. their feelings and ideas about teaching iSTEM, such as perceived relevance, anxiety, and self-efficacy) (Thibaut et al. 2018b). Teachers who have a more positive attitude towards iSTEM are more likely to adopt instructional practices that are congruent with the five key principles of iSTEM education. The study of Thibaut et al. (2018b) furthermore showed that teachers' attitudes towards the implementation of inquiry- and design-based learning are affected by support from the school management (in terms of appreciation, confidence, and involvement). Unsurprisingly, teachers' attitudes towards design-based learning are also related to technical aspects of the teaching context, such as availability of rooms and equipment (Thibaut et al. 2018b). Their propensity to integrate STEM learning contents in a problem-centred manner significantly depends on opportunities for them to collaborate with colleagues from different STEM 
disciplines (Thibaut et al. 2018b). The fact that management support, reflected in allocated, collective meeting time and some flexibility to experiment, is an indispensable ingredient for successful implementation also became obvious during the review meetings on the STEM@school learning units.

Participation in professional development is strongly and positively correlated with teachers' attitudes toward iSTEM (Thibaut et al. 2018c). It was therefore interesting to examine how participating in the collaborative design of the STEM@school learning units, as a form of professional development, had affected teachers' attitudes towards iSTEM. Semi-structured interviews were conducted to explore the effect of participation in the iSTEM TDTs on teachers' knowledge and attitudes towards (teaching) (i) STEM, and ultimately on the implementation of iSTEM practices. To this end, the reflections of a sample of teachers who were part of the iSTEM TDTs were compared with those of a sample of teachers who had merely implemented the designed learning units. The qualitative analysis revealed that teachers who had participated in the iSTEM TDTs showed a more pronounced sense of ownership and ideas more congruent with the key principles, a teaching style closer to coaching, and a more pronounced habit of learning from colleagues than their counterparts who had merely implemented the designed materials (De Meester 2019).

\section{Conclusions and Implications for Secondary STEM Education}

To prepare students to tackle tomorrow's challenges, we must provide them with the tools to do so and give them the kind of STEM education they are entitled to. We must thus show students the relevance of STEM subject matter and the fascinating way it helps resolve environmental problems. At the same time, we should equip them with robust understanding of this subject matter, fluency in making cross-disciplinary connections, critical thinking skills, inquisitiveness and creativity (Boon $\mathrm{Ng} 2019$ ). As a practice-based research project, STEM@school accomplished translating this view on STEM education into an approach and concrete learning materials for integrated STEM (iSTEM) in middle and upper secondary education. During the four project years, the teachers' design process, classroom practices and attitudes, and students' conceptual understanding and attitudes were studied with respect to the STEM@school approach towards iSTEM curriculum design and implementation. This approach was grounded in five key principles: (1) integration of STEM subject matter; (2) problem-centred learning; (3) inquiry- and design-based learning; (4) cooperative learning; and (5) input from discipline-specific pedagogical research. By bringing STEM teachers and educational researchers together in integrated STEM teacher design teams (iSTEM TDTs), STEM@school managed to bridge the gap between secondary and higher STEM education.

This collaboration ensured a clear view on the curriculum standards, behaviour and interests of the student target group on the one hand, and the incorporation of developments in science and technology education research and some outside the box thinking (i.e. thinking outside the curricula) on the other hand. This collaboration 


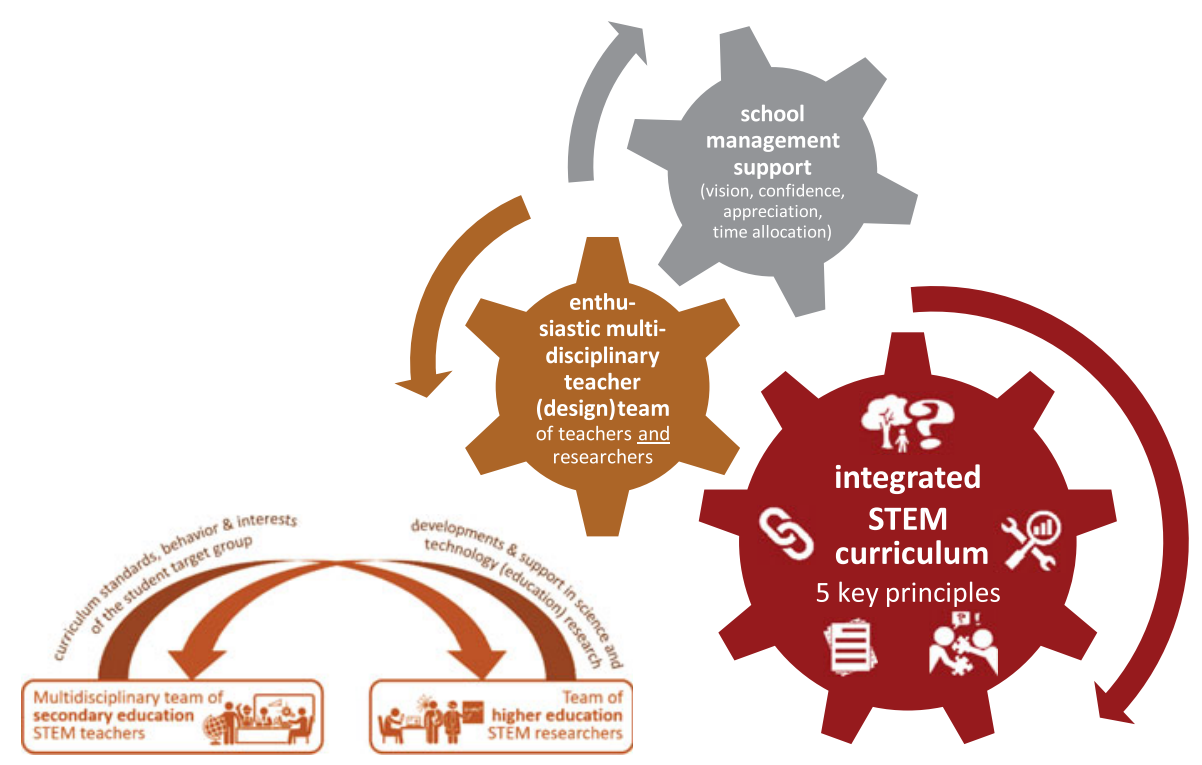

Figure 4. Ingredients for successful implementation of iSTEM education.

was continued during the implementation of the learning units, which significantly facilitated the research and review process. The results of the iSTEM approach of STEM@school in terms of student and teacher learning outcomes are promising. Classroom practices corresponding to the five key principles of iSTEM education improved students' ability to solve both monodisciplinary and integrated problems on mathematics, physics and technology concepts. In addition, students' interests in STEM and STEM careers and their collective classroom engagement were positively affected by the iSTEM approach of STEM@school. These results complement other research findings on integrated STEM education (Becker and Park 2011; Kutch 2011; Gottfried \& Bozick 2016; Ross \& Hogaboam-Gray 1998; Kiray \& Kaptan 2012; Sungur et al. 2010; Yildirim 2016). However, and especially now the teething troubles have been weeded out, while students autonomously tackle the authentic challenges designed by STEM@school, caution must be taken to ensure a robust understanding of key scientific concepts, and to provide enough structure in order to enhance students' self-efficacy in STEM (Ceuppens 2019; De Loof et al. 2019). In line with other research on collaborative curriculum design (Voogt et al. 2011; Coenders and Terlouw 2015; James et al. 2000), our research found positive effects on teachers' attitudes as a result of participating in the iSTEM TDTs of STEM@school, which in turn will foster the enactment of the five key principles of iSTEM education in the classroom.

As shown in Figure 4, the approach and findings of STEM@school entail some implications for school teachers, management, educators and faculty members who want to transform their mathematics, science and technology education into integrated STEM education. First, it is important to gather a motivated community 
of practice. The support of a school management that encourages and allocates time for cross-disciplinary discourse and collaboration among its teacher team is crucial to the successful design and implementation of an integrated STEM curriculum. The STEM teachers taking part in this educational transformation should be enthusiastic, willing to donate a lot of their free time, and eager for lifelong learning in and across STEM disciplines. A liaison between secondary and higher institutions promotes further cross-fertilization, since it creates opportunities to gather and incorporate evidence of good practices in a methodological way while experimenting with the new instructional approach. An inspiring kick-off meeting, in which a clear vision of the objectives and approach towards iSTEM is presented, can instigate this collaborative change process and get every important stakeholder on board. Close adherence to the curriculum standards of the separate STEM courses is an extra argument that often helps to win over the hearts of teachers who initially appear reluctant to use the new approach.

The implementation of each of the five key principles of iSTEM education is important, since it will warrant better results in terms of learning outcomes. As main influencers, STEM teachers play a pivotal role in this educational transformation. The more teachers' attitudes correspond with the key principles, the higher their self-efficacy and the more likely they are to implement instructional practices that are congruent with these principles. Therefore, plenty of, and adequate, opportunities for professional development should be provided for both in-service and pre-service teachers. Grouping them in iSTEM TDTs proved to be an effective form of such professional development, as the challenge of the design process has teachers play the whole game (see Perkins 2010) and embody the key principles of iSTEM themselves. Based on the experiences and findings of STEM@school, we recommend forming teams of teachers from multiple STEM disciplines (mathematics, physics, chemistry, geography, biology, electricity, mechanics, computer science, and so on) and from different educational levels to maximize cross-fertilization and alignment. As a guide, the teams and team coaches can make use of the platform CODEM for iSTEM (Cooperative Online Design of Educational Materials for integrated STEM), which is the result of a case study in which four STEM@school TDTs were followed and observed up close during their design process (De Meester 2019).

Currently, the insights gathered by STEM@school are being propagated into different Flemish secondary school levels and programmes (also in the less STEMoriented tracks and tracks with a lower abstraction level). In pre- and in-service teacher education, CODEM for iSTEM is being implemented and upgraded (see for example https://istem.be/professionalisering/) in order to continue the momentum initiated by STEM@school to prepare teachers for iSTEM education in accordance with the five key principles. The ambition is to expand the positive impact of integrated STEM on youngsters' knowledge and attitudes towards mathematics, science and technology, which will eventually lead to a higher and more qualified enrolment in highereducation STEM programmes. 


\section{References}

Aschbacher PR, Li E and Roth EJ (2010) Is science me? High school students' identities, participation and aspirations in science, engineering, and medicine. Journal of Research in Science Teaching: The Official Journal of the National Association for Research in Science Teaching 47(5), 564-582, https://doi.org/10.1002/tea. 20353.

Ardies J, De Maeyer S and Gijbels D (2013) Reconstructing the pupils attitude towards technology-survey. Design and Technology Education 18(1), 8-19.

Barab S and Squire K (2004) Design-based research: putting a stake in the ground. The Journal of the Learning Sciences 13(1) 1-14, https://doi.org/10.1207/ s15327809j1s1301_1.

Becker FS (2010) Why don't young people want to become engineers? Rational reasons for disappointing decisions. European Journal of Engineering Education 35(4), 349-366, https://doi.org/10.1080/03043797.2010.489941.

Becker K and Park K (2011) Effects of integrative approaches among science, technology, engineering, and mathematics (STEM) subjects on students' learning: a preliminary meta-analysis. Journal of STEM Education: Innovations and Research 12(5/6), 23.

Bennecke VM and Lohel V (2009) Nachwuchsbarometer Technikwissenschaften. Careers in Science and Engineering: Trends, Expectations and Attitudes of Young People. Munich/Düsseldorf: acatech, VDI, https://en.acatech.de/ publication/nachwuchsbarometer- echnikwissenschaften-careers-in-science-andengineering-trends-expectations-and-attitudes-of-young-people/.

Biggs J (1996) Enhancing teaching through constructive alignment. Higher Education 32(3), 347-364, https://doi.org/10.1007/BF00138871.

Boon Ng S (2019) Exploring STEM competences for the 21st century. Current and Critical Issues in Curriculum, Learning and Assessment 30. Geneva: IBEUNESCO, https://unesdoc.unesco.org/ark:/48223/pf0000368485.locale=en.

Capraro MM and Jones M (2013) Interdisciplinary STEM project-based learning. In Capraro RM, Capraro MM and Morgan JR (eds), STEM Project-based Learning. Rotterdam: SensePublishers, pp. 51-58.

Caprile M, Palmen R, Sanz P and Dente G (2015) Encouraging STEM Studies: Labour Market Situation and Comparison of Practices Targeted at Young People in Different Member States. Brussels: European Union, https://hdl. voced.edu.au/10707/371460.

Ceuppens S (2019) Learning of Physics and Mathematics Concepts in an Integrated STEM Curriculum. PhD dissertation. Leuven: KU Leuven.

Ceuppens S, Deprez J, Dehaene W and De Cock M (2018) Design and validation of a test for representational fluency of 9 th grade students in physics and mathematics: the case of linear functions. Physical Review Physics Education Research 14(2), 020105, https://doi.org/10.1103/PhysRevPhysEducRes.14.020105.

Ceuppens S, Bollen L, Deprez J, Dehaene W and De Cock M (2019) 9th grade students' understanding and strategies when solving $x(t)$ problems in 1D kinematics and $y(x)$ problems in mathematics. Physical Review Physics Education Research 15, 010101, https://doi.org/10.1103/PhysRevPhysEducRes.15.010101.

Cleaves A (2005) The formation of science choices in secondary school. International Journal of Science Education 27(4), 471-486, https://doi.org/10. 1080/0950069042000323746.

Chen X (2013) STEM Attrition: College Students' Paths Into and Out of STEM Fields (NCES 2014-001). Washington, DC: National Center for Education 
Statistics, Institute of Education Sciences, US Department of Education, https:// files.eric.ed.gov/fulltext/ED544470.pdf.

Coenders F and Terlouw C (2015) A model for in-service teacher learning in the context of an innovation. Journal of Science Teacher Education 26(5), 451-470, https://doi.org/10.1007/s10972-015-9432-5.

Conley DT (2007) Redefining College Readiness. Eugene, OR: Educational Policy Improvement Center (NJ1).

De Loof H (2019) Educating Engaged and Competent Students for STEM: Effects of Integrated STEM Education. PhD dissertation. Antwerp: University of Antwerp.

De Loof H, Struyf A, Boeve-de Pauw J and Van Petegem P (2019) Teachers' motivating style and students' motivation and engagement in STEM: the relationship between three key educational concepts. Research in Science Education 1-19, https://doi.org/10.1007/s11165-019-9830-3.

De Meester J (2019) Designing iSTEM Learning Materials for Secondary Education. $\mathrm{PhD}$ dissertation. Leuven: KU Leuven.

De Meester J, De Cock M, Knipprath H and Dehaene W (2015) Een nieuwe didactiek, richting abstract geïntegreerd STEM-onderwijs [New pedagogies, towards abstract, integrated STEM education]. Impuls voor Onderwijsbegeleiding 46(1), $3-11$.

Dumitru D, Bigu D, Elen J, Jiang L, Railienè A, Penkauskienè D and Palaigeorgiou G (2018) A European Collection of the Critical Thinking Skills and Dispositions Needed in Different Professional Fields for the 21st Century. Vila Real: UTAD, https://hdl. handle.net/10197/9840.

English LD (2017) Advancing elementary and middle school STEM education International Journal of Science and Mathematics Education 15(1), 5-24, https:// doi.org/10.1007/s10763-017-9802-x.

European Commission (2010) Special Eurobarometer 340. Science and Technology Report. January 2010 - February 2010. Brussels: TNS Opinion \& Social.

European Commission (2017) 10 Trends Transforming Education As We Know It. European Political Strategy Centre. https://doi.org/10.2872/800510.

Eurostat (2018) Distribution of Tertiary Education Students by Field and Sex, EU-28 2016. Kirchberg: European Commission. Available at https://ec.europa.eu/eurostat/ statistics-explained/index.php?title=File:Distribution_of_tertiary_education students_by_field_and_sex,_EU-28,_2016_(\%25)_ET18.png (accessed 28 October 2019).

EU STEM Coalition (2016) STEM Skills for a Future-proof Europe. Fostering Innovation, Growth and Jobs by Bridging the EU STEM Skills Mismatch. The Hague: European Union. https://www.aede-france.org/ERASMUS-DAY-EUSTEM-Brochure.html.

Flemish Government (2012) Actieplan voor het stimuleren van loopbanen in wiskunde, exacte wetenschappen en techniek 2012-2020 [Action Plan for the Stimulation of Careers in Mathematics, Exact Sciences, and Technology 2012-2020]. Brussels: Flemish Parliament.

Flemish Government (2015) STEM-monitor 2015 - indicatoren [STEM Monitor 2015 Indicators ]. Brussels: Department of Education and Formation.

Flemish Government (2018) STEM-monitor 2018 - indicatoren [STEM Monitor 2018 Indicators]. Brussels: Department of Education and Formation.

Fortus D, Krajcik J, Dershimer RC, Marx RW and Mamlok-Naaman R (2005) Design-based science and real-world problem-solving. International Journal of Science Education 27(7), 855-879, https://doi.org/10.1080/09500690500038165. 
Goovaerts L (2019) Development and Assessment of iSTEM Competencies. $\mathrm{PhD}$ dissertation. Leuven: KU Leuven.

Goovaerts L, De Cock M and Dehaene W (2016) Assessment of STEM-design challenges: review and design. Proceedings of the International Conference GIREP \& EPEC 2015 - Key Competences in Physics Teaching and Learning, 45-51.

Goovaerts L, De Cock M, Struyven K and Dehaene W (2019a) Developing a module to teach thermodynamics in an integrated way to 16 year old pupils. European Journal of STEM Education 4(1), 2, https://doi.org/10.20897/ejsteme/3964.

Goovaerts L, De Cock M, Struyven K and Dehaene W (2019b) A concrete proposal to introduce control theory to 16 year-old pupils. European Journal of STEM Education 4(1), 6, https://doi.org/10.20897/ejsteme/5757.

Gottfried MA and Bozick R (2016) Supporting the STEM pipeline: linking applied STEM course-taking in high school to declaring a STEM major in college. Education Finance and Policy 11(2) 177-202, https://doi.org/10.1162/ EDFP_a_00185.

Halpern DF (1998) Teaching critical thinking for transfer across domains: disposition, skills, structure training, and metacognitive monitoring. American Psychologist 53(4), 449-455, http://dx.doi.org/10.1037/0003-066X.53.4.449.

James RK, Lamb CE, Householder DL and Bailey MA (2000) Integrating science, mathematics, and technology in middle school technology-rich environments: a study of implementation and change. School Science and Mathematics 100(1) 27-35, https://doi.org/10.1111/j.1949-8594.2000.tb17317.x.

Kelley TR and Knowles JG (2016) A conceptual framework for integrated STEM education. International Journal of STEM Education 3(1) 11, https://doi.org/10. 1186/s40594-016-0046-z.

Kiray SA and Kaptan F (2012) The effectiveness of an integrated science and mathematics programme: science-centred mathematics-assisted integration. Online Submission, Energy Education Science \& Technology Part B: Social and Educational Studies 4(2), 943-956.

Knipprath H, Thibaut L, Buyse MP, Ceuppens S, De Loof H, De Meester J, ... Dehaene W (2018) STEM education in Flanders: how STEM@school aims to foster STEM literacy and a positive attitude towards STEM. IEEE Instrumentation \& Measurement Magazine 21(3), 36-40, https://doi.org/10.1109/MIM.2018. 8360917.

Kolmos A, Mejlgaard N, Haase S and Holgaard JE (2013) Motivational factors, gender and engineering education. European Journal of Engineering Education 38(3), 340-358, https://doi.org/10.1080/03043797.2013.794198.

Kutch M (2011) Integrating science and mathematics instruction in a middle school STEM course: the impact on attitudes, career aspirations and academic achievement in science and mathematics. ProQuest Dissertations and Theses 196.

Lichtenberger A, Wagner C, Hofer SI, Stern E and Vaterlaus A (2017) Validation and structural analysis of the kinematics concept test. Physical Review Physics Education Research 13, 010115, https://doi.org/10.1103/PhysRevPhysEducRes. 13.010115 .

Meeder H (2014) What is ‘STEM Literacy'? 12 August 2014. Available at http://nc3t. com/stem-literacy/ (accessed 28 October 2019).

Morgan SL, Gelbgiser D and Weeden KA (2013) Feeding the pipeline: gender, occupational plans, and college major selection. Social Science Research 42(4), 989-1005, https://doi.org/10.1016/j.ssresearch.2013.03.008. 
NAE and NRC (2014) STEM Integration in K-12 Education: Status, Prospects, and an Agenda for Research, edited by Honey M, Pearson G and Schweingruber $\mathrm{H}$. Washington, DC: The National Academies Press.

OECD (2016) PISA 2015 Results (Volume I): Excellence and Equity in Education, PISA. Paris: OECD Publishing. https://doi.org/10.1787/9789264266490-en.

Perkins D (2010) Making Learning Whole: How Seven Principles of Teaching can Transform Education. San Francisco, CA: Jossey-Bass.

Rayner G and Papakonstantinou T (2015) Employer perspectives of the current and future value of STEM graduate skills and attributes: an Australian study. Journal of Teaching and Learning for Graduate Employability 6(1) 100-115, https://doi. org/10.21153/jtlge2015vol6no1art576.

Reeve J, Jang H, Carrell D, Jeon S and Barch J (2004) Enhancing students' engagement by increasing teachers' autonomy support. Motivation and Emotion 28(2) 147-169, https://doi.org/10.1023/B:MOEM.0000032312.95499.6f.

Reeves TC, Herrington J and Oliver R (2005) Design research: a socially responsible approach to instructional technology research in higher education. Journal of Computing in Higher Education 16(2), 96-115, https://doi.org/10.1007/ BF02961476.

Ross JA and Hogaboam-Gray A (1998) Integrating mathematics, science, and technology: effects on students. International Journal of Science Education 20(9) 1119-1135, https://doi.org/10.1080/0950069980200908.

Satchwell RE and Loepp FL (2002) Designing and implementing an integrated mathematics, science, and technology curriculum for the middle school. Journal of Industrial Teacher Education 39(3).

Sawada D, Piburn MD, Judson E, Turley J, Falconer K, Benford R and Bloom I (2002) Measuring reform practices in science and mathematics classrooms: the reformed teaching observation protocol. School Science and Mathematics 102(6) 245-253, https://doi.org/10.1111/j.1949-8594.2002.tb17883.x.

Sheldrake R, Mujtaba T and Reiss MJ (2017) Science teaching and students' attitudes and aspirations: The importance of conveying the applications and relevance of science. International Journal of Educational Research 85 167-183, https://doi.org/10.1016/j.ijer.2017.08.002.

Shernoff DJ, Sinha S, Bressler DM and Ginsburg L (2017) Assessing teacher education and professional development needs for the implementation of integrated approaches to STEM education. International Journal of STEM Education 4(13), https://doi.org/10.1186/s40594-017-0068-1.

Sjøberg S and Schreiner C (2010) The ROSE Project: An Overview and Key Findings. Oslo: University of Oslo.

Streveler RA, Litzinger TA, Miller RL and Steif PS (2008) Learning conceptual knowledge in the engineering sciences: overview and future research directions. Journal of Engineering Education 97(3) 279-294, https://doi.org/10.1002/j.21689830.2008.tb00979.x.

Struyf A, De Loof H, Boeve-de Pauw J and Van Petegem P (2019) Students' engagement in different STEM learning environments: integrated STEM education as promising practice? International Journal of Science Education 41(10) 13871407, https://doi.org/10.1080/09500693.2019.1607983.

Sungur S, Tekkaya C and Geban Ö (2010) Improving achievement through problembased learning. Journal of Biological Education 40(4) 155-160, https://doi.org/10. 1080/00219266.2006.9656037. 
Thibaut L (2018) Implementing Integrated STEM. Teachers' Attitudes, Instructional Practices and Students' Learning Outcomes. PhD dissertation. Leuven: KU Leuven.

Thibaut L, Ceuppens S, De Loof H, De Meester J, Goovaerts L, Struyf A, ... Depaepe F (2018a) Integrated STEM education: a systematic review of instructional practices in secondary education. European Journal of STEM Education 3(1), 2.

Thibaut L, Knipprath H, Dehaene W and Depaepe F (2018b) The influence of teachers' attitudes and school context on instructional practices in integrated STEM education. Teaching and Teacher Education 71 190-205, https://doi.org/10.1016/ j.tate.2017.12.014.

Thibaut L, Knipprath H, Dehaene W and Depaepe F (2018c) How school context and personal factors relate to teachers' attitudes toward teaching integrated STEM. International Journal of Technology \& Design Education 28(3), 631-651, https:// doi.org/10.1007/s10798-017-9416-1.

Tseng KH, Chang CC, Lou SJ and Chen WP (2013) Attitudes towards Science, Technology, Engineering and Mathematics (STEM) in a project-based learning $(\mathrm{PjBL})$ environment. International Journal of Technology and Design Education 23(1), 87-102, https://doi.org/10.1007/s10798-011-9160-x.

Van den Berghe W and De Martelaere D (2012) Kiezen voor STEM. De keuze van jongeren voor technische en wetenschappelijke studies. Brussels: Flemish Council for Science and Innovation, https://www.vlaanderen.be/publicaties/kiezen-voorstem-de-keuze-van-jongeren-voor-technische-en-wetenschappelijke-studies-studiereeks.

Voogt J, Westbroek H, Handelzalts A, Walraven A, McKenney S, Pieters J and De Vries B (2011) Teacher learning in collaborative curriculum design. Teaching and Teacher Education 27(8) 1235-1244, https://doi.org/10.1016/j.tate.2011.07.003.

Williams JD (2011) How Science Works: Teaching and Learning in the Science Classroom. London: Continuum.

World Economic Forum (2016) The Future of Jobs: Employment, Skills and Workforce Strategy for the Fourth Industrial Revolution. Cologny/Geneva: World Economic Forum.

Yildirim B (2016) An analysis and meta-synthesis of research on STEM education. Journal of Education and Practice, 7(34) 23-33, https://doi.org/10.7176/JEP.

\section{About the Authors}

Jolien De Meester, PhD, is Postdoctoral Researcher, Faculty of Engineering Science, KU Leuven (BE); Teacher Trainer, Master of Teaching in Science and Technology programme, KU Leuven (BE) (2019-); STEM@school project researcher (2014 2018); Teaching Assistant, Department of Electromechanical Engineering, Group T University College (2009-2012). His publications are on integrated STEM education and its design process, and his $\mathrm{PhD}$ dissertation was entitled Designing iSTEM Learning Materials for Secondary Education (2019).

Jelle Boeve-De Pauw, PhD, is Postdoctoral Researcher, EduBROn, Department of Training and Education Sciences, University of Antwerp (BE) (2011-); Teacher Trainer, Head of Expertise Centre 'Urban Education', Karel de Grote University College (BE) (2017-); Postdoctoral Researcher, SMEER Group, Karlstad 
University (SE) (2016-); Communication Officer, Belgian National Focal Point to the Convention on Biological Diversity (2006); Science Exposition Developer, Museum of natural Sciences (2005); ENEC representative (2017-); Artifex ERASMUS+ partner (2017-); VALIES project coordinator (2017-2020); STEM@school project partner (2014-2018); and Associate Editor of Environment, Sustainability and Development (ENVI). His fields of research are educational effectiveness, education for sustainable development, STEM education and socio-scientific issues, diversity, cross-cultural psychology and interculturality. Among his books are Knowledge and Environmental Citizenship (2020), Conceptualizing Environmental Citizenship for 21st Century Education (2020), Valuing the Invaluable (2011).

Marie-Paule Buyse, MSc, is Project Staff Member, Cel iSTEM inkleuren, KU Leuven (BE) (2019-); Project Staff Member, STEM@school, Department of Electrical Engineering ESAT-MICAS, KU Leuven (BE) (2017-2018); Policy Advisor, Faculty of Engineering Science, KU Leuven (BE) (2006-2016); Student Coach, Tutorial Services, Faculty of Science, KU Leuven (BE) (1990-2005). Her publications are on integrated STEM education, stimulating learning environments at the Faculty of Science, accreditation and quality assurance, educational and international matters and project-based learning in engineering education.

Stijn Ceuppens, PhD, is Project Staff Member, Cel iSTEM inkleuren, KU Leuven (BE) (2019-); Project Staff Member, SCK-CEN (2018-2019); STEM@school project researcher (2015-2018); His publications are on integrated STEM and on the learning of physics and mathematics concepts in secondary education. His $\mathrm{PhD}$ dissertation was entitled Learning of Physics and Mathematics Concepts in an Integrated STEM Curriculum (2019).

Mieke De Cock, PhD, is Professor, Department of Physics and Astronomy, KU Leuven (BE) (2007-); Teacher Trainer, Artevelde University College (2003-2006); Team Leader of the LESEC theme on Conceptual Understanding and Problem Solving; Chair of the Working Group on Educational Research in the context of the Master of Teaching Programme, KU Leuven (BE); STEM@school project partner (2014-2018). Her fields of research are astronomy/astrophysics and physics education research and integrated STEM education, at different educational levels. She has $200+$ publications in national and international journals and volumes.

Haydée De Loof, $\mathrm{PhD}$, is Researcher, EduBROn, Department of Training and Education Sciences, University of Antwerp (BE) (2014-); Researcher, Tutorial Services, Department of Educational Matters, University of Gent (2019); Artifex ERASMUS+ researcher (2017-); STEM@school project researcher (2014-2018). Her publications are on the effects of integrated STEM education on students' knowledge and attitudes. Her $\mathrm{PhD}$ dissertation was Educating Engaged and Competent Students for STEM. Effects of Integrated STEM Education (2018). 
Leen Goovaerts, $\mathrm{PhD}$, is Guest Professor and Teacher Trainer, Faculty of Social Sciences/School of Education, University of Antwerp (BE) (2019-); Teaching Assistant, Department of Sustainable Chemical Process Technology, KU Leuven (BE) (2019-); STEM@school project researcher (2014-2018). Her publications are on development of integrated STEM learning materials and on assessment of integrated STEM practices. Her PhD dissertation was entitled Development and Assessment of iSTEM Competencies (2019).

Luc Hellinckx, MSc, is Cross-Faculty Coordinator, Vrije Universiteit Brussel (BE) (2018-); Pedagogical advisor, School Boards of Education of the Flemish Community (BE) (2014-2018); STEM@school project associate (2016-2018).

Heidi Knipprath, PhD, is Research expert, Research Group Education and Labour Market, Research Institute for Work and Society, KU Leuven (BE) (2010-); Postdoctoral Researcher, Faculty of Psychology and Educational Sciences, KU Leuven (BE) (2006-2010); Senior Researcher, Noordelijke Rekenkamer (20052006); Lecturer, School of Management and Governance, University of Twente (2001-2005); Guest Professor, Maizuru National College of Technology (19992001); ENLIVEN H2020 project partner (2018-); G3WM3M researcher (2017-); STEM@school project coordinator (2014-2018). Her fields of research are educational effectiveness (including STEM education), monitoring and evaluation and school-to-work transition. Among her books are: Quality and Equity: Japanese Education in Perspective (2005). Various publications in national and international journals and volumes.

Annemie Struyf, PhD, is Postdoctoral Researcher, Centre for Migration and Intercultural Studies, Department of Sociology, University of Antwerp (BE) (2019-); Guest Professor, Faculty of Social Sciences/School of Education, University of Antwerp (BE) (2019-; STEM@school project researcher (20142018). Her publications are on the role of integrated STEM learning environments. Her PhD dissertation was entitled How to Engage Students for STEM? Analysing the Ingredients for a Motivational Cocktail in the Learning Environment (2019).

Lieve Thibaut, PhD, is Didactic Project Manager, i-Learn, IMEC (2019-); Researcher, Centre for Languages and Education, KU Leuven (BE) (2019); Biomedical Engineer, Engineering World Health (2018); STEM@school project researcher (2014-2018). Her publications are on the effects of integrated STEM education and practices. Her $\mathrm{PhD}$ dissertation is entitled Implementing Integrated STEM. Teachers' Attitudes, Instructional Practices, and Students' Learning Outcomes (2018).

Didier Van de Velde, MSc Eng, is Pedagogical advisor, School boards associated with the Catholic school's network in Flanders (BE) (2014-); Educational advisor, Curriculum agency of the Flemish Government (2011-2014); Teacher trainer and researcher, Artevelde University College of Applied Sciences (1998-2011); 
STEM@school project associate (2014-2018). He has published in several national and international journals and volumes in the field of technology education.

Peter Van Petegem, PhD, is Full Professor, EduBROn, Department of Training and Education Sciences, University of Antwerp (BE) (1999-); Part-time Research Professor at the Norwegian University of Science and Technology, Trondheim (NO); Editor-in-Chief of Studies in Educational Evaluation; Editorial Board Member of Environmental Education Research. His publications are on school and education policies, quality concern, environmental education, STEM education, and education for sustainable development. He has contributed to $50+$ books on a variety of educational and didactical topics, and $200+$ articles in international journals and volumes.

Wim Dehaene, PhD, is Professor, Head of MICAS Research Group, Department of Electrical Engineering ESAT, KU Leuven (BE) (2002-); Senior Researcher, IMEC (2002-); Senior Project Manager, Alcatel Microelectronics (1996-2001); IEEE senior member; Cel iSTEM Inkleuren coordinator (2019-); ISSCC Program Committee member (2011-2014); ESSCIRC Technical Program Committee member; STEM@school project coordinator (2014-2018). His fields of research are circuit level design of digital circuits (with a current focus on ultra-low power signal processing and memories in advanced CMOS technologies), and pedagogies in Engineering and STEM. Among his books are: Efficient Design of VariationResilient Ultra-Low Energy Digital Processors (2019), Robust Design of Digital Circuits on Foil (2016), Ultra-Low-Voltage Design of Energy-Efficient Digital Circuits (2015). He has $300+$ articles in national and international journals and volumes. 